This is an electronic reprint of the original article. This reprint may differ from the original in pagination and typographic detail.

Author(s): Palmujoki, Eero; Virtanen, Pekka

Title: Global, National, or Market? : Emerging REDD+ Governance Practices in Mozambique and Tanzania

Year: $\quad 2016$

Version:

Please cite the original version:

Palmujoki, E., \& Virtanen, P. (2016). Global, National, or Market? : Emerging REDD+ Governance Practices in Mozambique and Tanzania. Global Environmental Politics, 16(1), 59-78. https://doi.org/10.1162/GLEP_a_00338

All material supplied via JYX is protected by copyright and other intellectual property rights, and duplication or sale of all or part of any of the repository collections is not permitted, except that material may be duplicated by you for your research use or educational purposes in electronic or print form. You must obtain permission for any other use. Electronic or print copies may not be offered, whether for sale or otherwise to anyone who is not an authorised user. 


\title{
Global, National, or Market? Emerging REDD+ Governance Practices in Mozambique and Tanzania
}

\author{
Eero Palmujoki and Pekka Virtanen*
}

\begin{abstract}
This article examines emerging governance practices in the REDD (Reducing Emissions from Deforestation and Forest Degradation) initiative. We examine three different general governance practices (neoliberal, post-national, and government-led practices) that have been applied in the interaction between international organizations and two REDD target countries: Mozambique and Tanzania. In these countries, we find that emerging REDD+ governance practices are a mixture of international organizations' procedural practices and the target country's established governance practices, whereas neoliberal practices are weakly expressed. These findings call into question the simplified assumption of reduced state authority.
\end{abstract}

In the Copenhagen Climate Summit of 2009, REDD (Reducing Emissions from Deforestation and Forest Degradation) was chosen as one of the major instruments in fighting climate change. In the REDD scheme, developing countries can contribute to the mitigation targets of the UN Framework Convention on Climate Change (UNFCCC) by trading carbon assets stored in their forests on global carbon markets or through direct transactions from developed to developing countries. This reflects a compromise between many different interests. For developed countries, it is the answer to the question of how to include developing countries in efforts aimed at mitigating greenhouse gases (GHGs). For developing countries, it is a novel way to fund climate-related development. For business, it is an opportunity to broaden the carbon trade business in new markets; for the nongovernmental organizations (NGOs), a possibility to enforce civil society and include the voice of local people in environmental conservation and development. Several different environmental and social aspects have since been linked to the original idea of carbon storage in forests, which is now called REDD+ (Haug and Gupta 2013, 80-81; McDermott et al. 2011; Pistorius 2012).

* We would like to thank three anonymous reviewers for their valuable and constructive comments on drafts of this article.

Global Environmental Politics 16:1, February 2016, doi:10.1162/GLEP_a_00338

๑ 2016 by the Massachusetts Institute of Technology 
Though the REDD concept is well-studied, except for pilot projects it has yet to produce a functioning practice at the national level in any country. Aside from rich general studies on REDD governance (den Besten et al. 2014; Doherty and Schroeder 2011; Gupta 2012; Gupta et al. 2013a; Hayes and Persha 2010; Kashwan 2015; Murdiyarso et al. 2012; Olander et al. 2012; Somorin et al. 2012), field studies and critical assessments are available for some African countries, notably Mozambique and Tanzania-hence, our present focus (e.g., Beymer-Farris and Bassett 2012; Mustalahti et al. 2012; Mwakalobo et al. 2011; Nhantumbo 2011; Robinson et al. 2013; Sitoe et al. 2012). In this study, we investigate governance practices linked to REDD's purposes, particularly practices that address the positions of states, nonstate actors, and international organizations (IOs) regarding governance. We understand practice to be a routine activity, not an idiosyncratic one, meaning that our analysis focuses not on actors" intentions but only on their actions. Practice is "[an] ensemble of doings, sayings and things in a specific field of activity" (Arts et al. 2014, 6). It is an established discourse, connected to international and national governance activities. As such, practices-not intentions-are considered constitutive (Adler and Pouliot 2011, 7; Swidler 2001, 84-85).

Den Besten et al. (2014) have examined how international discourses have molded REDD to REDD+. Following this, we analyze how discursive national governance practices concur with global climate governance, namely by examining how the UNFCCC's REDD initiative has been transformed into national practices in Mozambique and Tanzania. In this context, practice does not refer to project implementation, but to documented practices in forest governance, whereby countries prepare for REDD+ implementation. In this sense, the key question is how these practices were adapted to accommodate national practices.

The next section of this article discusses practice in the context of REDD+ by locating REDD+ amid the general situation of global climate change and development practices advocated by, for example, the UNFCCC, the World Bank (WB), and UN agencies. By drawing on theoretical literature and research addressing environmental governance and forest policies, including REDD studies, we articulate three basic hypotheses regarding how governance practices are structured. In the third section, we examine the realization of these governance models in REDD readiness processes in Mozambique and Tanzania, focusing on official documents. We study how the practices promoted by IOs reformulate the practices inscribed in national processes through key tools, including the Readiness Preparation Proposal (R-PP) process promoted by the $\mathrm{WB}$, national REDD+ strategies, and different safeguard standards that the IOs use to guide and review the adaptation of international social and environmental concerns in national practices.

\section{International Climate Change Governance Practices and REDD+}

The discussion about financing REDD, which ranges from market-based mechanisms for offsetting emissions to approaches based on financing by external 
funds, underscores the lack of coherence in the debate of REDD governance (McAffee 2012; Pistorius 2012; West 2010). In response, several different hypotheses are necessary to examine the REDD initiative in its sundry variations and developments within the UNFCCC process (Gupta et al. 2013b). In this study, we reduce the discussion to three hypothetical types of practices: neoliberal, postnational, and government-led.

These three practices are drawn from theoretical debates on the role of the state in the globalizing world. They are meta-discourses that can be found in different spheres of environmental governance (Pülzl et al. 2014). Although discussion on the changing role of the state started from developed, industrialized countries, it has also been applied in developing countries. Basically, the debate is divided into two parts: the decrease of the state's role in (neoliberal) globalization, and its changing role ("hollowing" of the state) in the globalization process. The first issue is seen as particularly relevant in development studies when the international funding institutions' (IFIs) policies support marketization, privatization, and cuts in the public sector (Peck and Tickell 2002). The second approach more emphasizes changes in the roles of the governments and states within the process (Jessop 2004; Rhodes 1994).

When understanding these hypothetical categories as practices, we try to avoid the idea that certain policies represent purposeful intention. Quite the opposite-we suppose that organizations, governments, and business follow practices. Strongly established practices can be considered institutions, but they are, at the same time, socially and historically contingent. They are not inevitable, although they are continuous and stable (Arts et al. 2014, 5).

By dividing three governance practices into four dimensions according to the model developed by Swidler (2001) and Sending and Neumann (2011), we first suggest that REDD+ implementation consists of a set of procedural practices originating from general climate change and development practices. In effect, these procedural practices limit more concrete actions known as anchoring practices. In the case of climate change and development, the principle known as common but differentiated responsibilities (CDR) guides general practice for developing countries in mitigating climate change. Any implementation in a particular area-here, the REDD+ process-constitutes a procedural practice. In REDD they answer the question of how the connection to the CDR is made. The procedural practices adopted by REDD+ divide the process into different approaches, for which the general starting point is mitigation. International discourse from REDD to REDD+ incorporated adaptation and socioeconomic development (den Besten et al. 2014). There are differences in the procedural practices between the three types of governance practices. The emphases of different procedural practices take more concrete shape at the level of anchoring practices, which pertain only to a certain domain focusing on a specific community, such as IOs and governments. In the case of REDD, anchoring practices indicate (1) how the connection between national measures and global 
institutions is made, (2) what the practices of carbon sequestration and mitigation are, (3) how these practical measures are funded, (4) how various actors form national REDD governance, and (5) what links forest conservation to development. In their implementation, anchoring practices fan out into a greater number of more concrete, specific practices (Sending and Neumann 2011). Anchoring practices take a crucial place in this study because they show how shared general procedural practices can lead to dissimilar concrete, specific practices.

\section{Neoliberal, Postnational, and Government-Led REDD Practices}

In climate change governance, the starting point of the neoliberal approach is the commodification of carbon, which enables climate change mitigation through carbon markets (Lansing 2011). In REDD governance, neoliberal anchoring practices focus on mitigation through conservation, in which the connection to global market institutions is made through private and semi-public institutions, which harmonize the standards and principles for carbon trade (Stephan 2012). The main instruments for promoting large-scale forest conservation for carbon sequestration are economic incentives to forest owners and tenure holders to facilitate their participation in global carbon markets. Thus, conservation financing occurs by selling carbon assets to global markets, which is also expected to solve problems with local socioeconomic development (McAffee 2012).

The neoliberal approach involves rule by markets, which suggests that all resources should be valued and priced via market mechanisms. Such rule is assumed to function properly only when property rights are clearly defined under private ownership and the state's role is limited through deregulation (Peck and Tickell 2002). In this system, the state's role is to maintain essential judicial institutions to guarantee the market function, while inevitable minimal regulation is provided voluntarily by the private sector (Holmes 2011; Humphreys $2009,320)$. Voluntary participation that replaces control by public authorities is therefore seen to be an organic part of the neoliberal approach (Humphreys 2003). The IOs' practices establish neoliberal discourse globally, and their role in this framework is that of a panopticon for controlling the implementation of neoliberal policies worldwide (Arsel and Büscher 2012).

Critical studies have argued that the general flaw of neoliberal environmental governance is its narrow view of conservation (Brockington and Duffy 2010; Castree 2008a; Castree 2008b; Igoe and Brockington 2007), particularly in developing countries (Fletcher 2012; Milne and Adams 2012). Strong support for neoliberal REDD governance appears in the REDD initiative itself, as well as in different submissions presented by a group of non-Annex countries at COP 11 . However, the spectrum of REDD proposals in COP 11 includes both market-based and non-market-based initiatives, though most are variations of the "commodification of forest carbon stock for market-based governance" approach 
(Corbera 2012, 613; Okereke and Dooley 2010). Such revisions of the neoliberal doctrine in development practice can be called "inclusive neoliberalism" (Ruckert 2006) or "hybrid neoliberalism" (Peck and Tickell 2002, 383), because the doctrine cannot solve wider social and environmental issues. Therefore, new approaches, such as civil society engagement and participatory approaches, have become necessary (McCarthy 2005). These and other extensive revisions are particularly apparent under REDD+, in which a market-based system is less visible than in the original submissions (Okereke and Dooley 2010).

The emergence of the new aspects into market-based governance and, in fact, the different globalization tendencies call for increasing regulation, which is difficult to explore from a pure market perspective. Following Habermas (2001), we call the second hypothetical ensemble of established activities "postnational governance practices." Where neoliberal approaches derive governance practices from market practices, postnational approaches constitute global multilevel governance as a new phenomenon. Accordingly, international standards, which are essential parts of current governance practices and cannot be drawn purely from market practices, actually stem from different networks and new political units, including nongovernmental actors. By the same token, the role of states has not vanished, but instead has changed (Jessop 2004; Rhodes 1994). The emergence of nonstate actors from both civil society and the private sector, in domains traditionally reserved for public authorities and supranational regulations, characterizes the new practices. Initially, the concept of postnational was not based on the idea of market domination in social life, but on the complex structures of global governance, including the IOs' promotion of marketization, democratization, and civil society participation (Habermas 2001; Hedrick 2007; Scheuerman 2008).

The emerging practices of REDD reformulate the market-based vision to comply with the practice of a complex global climate and development network (see Haug and Gupta 2013). In postnational conditions, national practices occur within the limits of international regulation, whether the practices concern carbon trade institutions (such as monitoring procedures agreed in the UNFCCC process) or environmental and social safeguards established by the UN and WB. The connection of national practices to global institutions is made by common standards and by related monitoring, reporting, and verifying (MRV) practices already established by the UNFCCC (CDM Rulebook 2012; see also UNFCCC $2012,4)$. Global governance practices are not, however, immune to national discussions, which particularly feed back into the discussion about the framework for various approaches (FVA) under the UNFCCC, which has meant the recognition of different national funding mechanisms for REDD+ (ENB 2015).

Another aspect deriving from the postnational condition is that global concerns and their solutions (e.g., REDD) can lead to local problems, such as limited livelihood and population transfer, known as "glocal" problems, which call for broader local, national, and international solutions (Gupta et al. 2013b, 231-238). For REDD specifically, the danger is that a new influx of investment 
and competing interests for forest resources will compromise the rights of local communities (Dooley et al. 2011; Nhantumbo 2011; Odgaard and Maganga 2009). In response, IOs have developed procedural civil society engagement practices and safeguards to include local communities' interests in governance and ensure that investments do not create negative outcomes. In 2010 the parties to the UNFCCC agreed to a procedural practice consisting of seven safeguards, known as the Cancun Safeguards, that define broad criteria and principles to help developing countries establish and implement national safeguards to enhance the role of international standards in the REDD+ process (Daviet and Larsen 2012, 18-19; Herbertson 2012, 11).

Postnational practices emphasize the delegation of authority between different national and international, and private and public, actors. Though the state's retreat is apparent, it is not inevitable; instead, the new paradigm suggests that state actions are no longer defined by the sovereignty principle and national interests alone. Currently, states take shape within global networks characterized by increasing global regulations. However, whether or not governance practices are postnational on a domestic level is debatable. In many cases current concrete governance practices do not resonate with discursive postnational anchoring practices in developing countries, but instead with government-led practices.

This type of practice-government-led-is ostensibly opposite the other two. In general, government-led practice is based on the idea that although IOs prefer neoliberal economic policies, their power is not decisive; as such, attention should focus on a country's existing power structures (Sangmpam 2007). Several scholars have noted that REDD plans and applications do not suggest the emergence of market-based forest governance, but rather, increasing attempts of governments to strengthen their grip on national forest resources. One plausible reason for this is that global REDD governance is already fragmented, which gives plenty of space for national governments to develop national REDD projects (Gupta 2012; Haug and Gupta 2013) and reinforce their role over civil society and the market (Phelps et al. 2010; Robinson et al. 2013). Similarly, the main institutional alternative to market-based mechanisms-namely, multilateral climate funds that allocate resources to national funds-gives governments an opportunity to dominate the REDD process (Streck 2012). In short, the emphasis on the public sector suggests that government-led practice runs counter to neoliberal REDD governance.

In government-led approaches, the state's retreat is relative, meaning that sovereignty claims now appear as another form of global regulation. For example, the REDD+ process emphasizes the state's role in facilitating carbon trade, which also suggests that authorities have a strong grip on forest management (Phelps et al. 2010). Global regulation may limit state and private actors, yet it also reinforces the state's role as a domestic actor, thereby stressing the state's traditional role as legislator, not facilitator. From this point of view, governments tend to accommodate IO policies into their prevailing development policies. Although states are willing to take part in GHG mitigation via the carbon trade, they insist 
that financing forest conservation should occur through national funds, arguably to guarantee that the volatility of carbon asset prices does not endanger the country's development goals (Makundi 2011, 194-196; Nhamo and Bimha 2011, 118-123).

REDD governance models can be clarified by scrutinizing the ways in which the REDD practices promoted by IOs are expressed in national documents. IO policies address these kinds of governance models to varying degrees. Traditionally, the WB has emphasized public-private partnerships and marketization as part of the integration into global governance, whereas UN agencies have paid more attention to the development of social and environmental safeguards to regulate the globalization processes. When recipient countries apply IO-promoted policies by combining different practices, a distinct governance model unlike the original may emerge. These models do not appear in any pure form, however, but as a combination of different, sometimes contradictory, practices (Table 1).

\section{The Mozambican REDD Practices}

The REDD process in Mozambique began in 2008 when the Ministry of Agriculture (MINAG) developed and submitted a Readiness Project Idea Note (RPIN) to the WB's Forest Carbon Partnership Facility (FCPF). Initially, the work advanced on two tracks: toward preparation of the R-PP for the FCPF led by MINAG, and toward a national REDD+ strategy to inform the implementation of pilot projects led by the Ministry of Environment (MICOA), funded mainly by Norway. ${ }^{1}$ However, in early 2010 the government decided to halt the R-PP process to focus on the national strategy, of which a draft version was ready in August 2010. In early 2011, the government again revised its approach and decided to proceed with preparation of the R-PP (Sitoe et al. 2012). A final version was approved in early 2012, thereby releasing FCPF initial funding for the implementation process (World Bank 2013). In the interim, "further development of the national strategy was paused in order to align its further improvement and finalization after the FCPF-R-PP process was started" (RM $2013 \mathrm{~b}, 90)$. Some powerful actors, such as the Council of Ministers and private companies, have been eager to accelerate the process, but voluntary marketbased pilot projects have proved disappointing, due to the volatility of carbon markets. Other actors, including many civil society organizations (CSOs), are critical because they fear that forest-dependent communities will suffer, although the Mozambican CSO field is divided over the issue (CIP and AWEPA 2012; Quan et al. 2014). After a large preparation grant was received from the WB in mid-2013, the process has been under close WB guidance. In late 2013 a decree (70/2013; RM 2013a) that establishes procedures to approve REDD+ projects was enacted and published, and the preparatory work has been largely shifted to private

1. Since January 2015, the two ministries have been merged under the new Ministry for Land, Environment, and Rural Development. 
Table 1

Governance Practices of REDD+

\begin{tabular}{|c|c|c|c|}
\hline Practice & Neoliberal & Postnational & Government-Led \\
\hline General practice & CDR & CDR & CDR \\
\hline Procedural practice & $\begin{array}{l}\text { Mitigation } \\
\text { through } \\
\text { marketization }\end{array}$ & $\begin{array}{l}\text { Mitigation, } \\
\text { adaptation, } \\
\text { socioeconomic } \\
\text { development }\end{array}$ & $\begin{array}{l}\text { Voluntary mitigation, } \\
\text { adaptation, } \\
\text { socioeconomic } \\
\text { development }\end{array}$ \\
\hline \multicolumn{4}{|l|}{ Anchoring practices } \\
\hline $\begin{array}{l}\text { Connection to } \\
\text { global institutions }\end{array}$ & $\begin{array}{l}\text { MRV, public } \\
\text { and private } \\
\text { institutions of } \\
\text { carbon trade }\end{array}$ & $\begin{array}{l}\text { MRV, UNFCCC } \\
\text { institutions }\end{array}$ & $\begin{array}{l}\text { Through existing } \\
\text { public institutions }\end{array}$ \\
\hline $\begin{array}{l}\text { Principles of } \\
\text { carbon sequestration } \\
\text { and mitigation }\end{array}$ & $\begin{array}{l}\text { Privatization of } \\
\text { forest resources, } \\
\text { commercial } \\
\text { forestry }\end{array}$ & $\begin{array}{l}\text { Mixed public } \\
\text { and private } \\
\text { measures }\end{array}$ & $\begin{array}{l}\text { Byproducts of } \\
\text { socioeconomic } \\
\text { development }\end{array}$ \\
\hline Principles of funding & Market-based & $\begin{array}{l}\text { Various } \\
\text { approaches }\end{array}$ & $\begin{array}{l}\text { Financing through } \\
\text { national funds }\end{array}$ \\
\hline Principles of governance & $\begin{array}{l}\text { Markets and } \\
\text { civil society }\end{array}$ & $\begin{array}{l}\text { Public and } \\
\text { civil society }\end{array}$ & $\begin{array}{l}\text { Government } \\
\text { (+civil society) }\end{array}$ \\
\hline Principles of development & Market-driven & Safeguards & $\begin{array}{l}\text { Development } \\
\text { assistance }\end{array}$ \\
\hline
\end{tabular}

Note: CDR: Common but different responsibilities; MRV: monitoring, reporting, and verifying

consultants (FCPF 2014). ${ }^{2}$ The draft national strategy (henceforth "the strategy") and the R-PP have been the key documents for REDD in Mozambique.

The strategy's weak connection to global institutions refers to governmentled practice. The strategy puts very little emphasis on technical and operational aspects, such as MRV, which are condensed into three pages. Among the resources to be disbursed via the REDD+ fund, only 20 percent are allocated for operations, including the realization of MRV at the national level, while 80 percent are directed to investments in communities and other supporting activities such as research and afforestation (MICOA 2011). Such low emphasis does not seem to recognize the importance of technical capacities in REDD+ implementation (Sitoe et al. 2012, 4), which receives much more space in the

2. The decree is one of the first of this type of legislation in the world. A project license allows the holder to apply for international carbon credit certification and sell the credits on voluntary markets, and to have preferential treatment when the REDD+ legal framework is approved (RM 2013a, Art. 27). 
R-PP. The R-PP discourse on local communities, by contrast, focuses on services the communities can provide, such as ensuring collective action and reducing illegal activities, as well as raising awareness. Their role in the more technical aspects of REDD, including MRV, is limited to collecting secondary data to strengthen local ownership, while the government's technical monitoring capacity is strengthened through a bilateral project with Japan (FCPF 2014; RM 2013b).

In contrast to the strategy, which is critical of the potential harmful effects of large-scale commercial carbon sequestration projects (MICOA 2011), the R-PP tends to blame the rural population for deforestation and the leakage problem. Through REDD+, communities are expected to gradually reduce deforestation and receive benefits from forest products and environmental services. To achieve such targets, they should be assisted to improve their "primitive" agricultural methods and abandon the practice of shifting cultivation, as well as adopt new technologies that make wood energy production and usage more sustainable. In strategic actions, the R-PP prioritizes private-sector options, such as large-scale commercial agriculture investments and small and medium enterprises (RM 2013b).

Securing ownership rights to land and carbon stocks is considered crucial to the entire process. Both the strategy and the R-PP recognize that, despite a relatively sound legal and policy framework, weak law enforcement and policy implementation constitute a major stumbling block for REDD+. Problems are considered particularly acute for communal lands, because transparent concrete practices for negotiations between local communities and investors are lacking (MICOA 2011; RM 2013b). Interestingly, the new decree separates carbon credits from land tenure (RM 2013a, Arts. 1, 5).

The issue of property rights is closely tied to funding the REDD+ process. The strategy links carbon sequestration with broader national development goals, noting that the state already recognizes community land rights and thus should also recognize rural communities' rights to carbon and related benefits. In the case of private enterprises' carbon credit sales on voluntary carbon markets, the strategy stipulates that $60-80$ percent of receipts must go to local communities. At the same time, it highlights other government-led premises, such as national ownership and management of REDD+ financial resources by way of a national fund administered by a Mozambican bank (MICOA 2011).

Following the neoliberal tenets of the R-PP, funding via various, preferably market-based, mechanisms should be tested and evaluated by piloting privatesector participation. Yet, while the R-PP recognizes that consultations during the REDD+ preparation underscored that opportunity costs fall largely on local communities and individuals, it maintains that the benefits from REDD+ to the local population should primarily materialize indirectly as a result of improved access to social services, or else due to technical support and financing devoted to introducing technical improvements and new practices, not by direct payments (RM 2013b). While recognizing communities along with national 
and foreign public or private actors (including CSOs and private persons) as license holders, the new decree reflects a move toward postnational practices. It leaves benefit-sharing to market negotiations guided by further regulations, stipulating only the distribution of the license fee and carbon credit tax $(10 \%)$, which will be divided between the government $(80 \%)$ and local communities (20\%) (RM 2013a, Arts. 21, 33, 34).

The strategy emphasizes development goals and national ownership of REDD, as well as the need to establish nationally defined anchoring practices for REDD governance. Crucial policy statements underscore that environmental services, including carbon sequestration, belong to the sphere of national sovereignty and that REDD+ must pose benefits to different segments of society, in particular to rural communities. The proposed REDD+ National Council would consist of representatives of various government directorates, civil society and research institutions, and one representative of the private sector (MICOA 2011). In contrast, the R-PP calls for more substantial private-sector representation in REDD+ decision-making bodies, including that of organizations established for community participation (RM 2013b). In this sense, it stresses neoliberal, businessbased, market-driven governance, whereas the strategy emphasizes public management with CSO engagement. The main supervisory body established in the decree, the REDD+ Technical Review Committee-which consists of 13 representatives of the government, six of civil society, three of research institutions, and two of the private sector (RM 2013a, Art. 10)-reflects the latter approach.

In terms of significant anchoring practices regarding social and environmental aspects of development, the strategy relies primarily on existing national institutions, while the R-PP uses the Strategic Environmental and Social Assessment (SESA) framework: the main technical instrument of the WB (MICOA 2011; RM 2013b). In the Mozambican REDD process, the R-PP requires the development of a detailed plan of consultation within SESA using the FCPF framework, which has been in preparation since January 2013. The chief output of the process is the development of safeguards to minimize the negative impacts of REDD+ implementation (FCPF 2014; RM 2013b, 102, 148). In this context, the R-PP seconds criticism of the way that existing national mechanisms, such as the public consultations required for natural resource initiatives in Mozambique, have been conducted, since these mechanisms sometimes involve manipulation and investor-based corruption, or else raise unfulfilled expectations of benefits for local communities (RM 2013b, 34). However, the same criticism has been leveled against the consultation processes led by the WB, including that "the FCPF's rules and commitments are largely confined to procedural rights to participation and consultation, rather than respecting substantive rights to land, livelihoods, and resources" (Dooley et al. 2011, 33). More broadly, the lack of capacity-and, arguably, political will-to enforce the existing normative framework for natural resource management, which the new decree also fails to address (Quan et al. $2014,18)$, creates a major obstacle for translating the established anchoring practices into concrete practices. 


\section{The Tanzanian REDD Practices}

REDD preparations also began in Tanzania in 2008, when the government reached an agreement with three chief donors. In financial terms, the primary donor was again Norway, which provides substantial funding for pilot programs addressing deforestation, developing methodologies for carbon accounting, promoting research and capacity building on climate change, enhancing investments in sustainable forest management, and assisting Tanzania with preparing for future REDD+ funding. In the same year, the R-PIN was developed and submitted to the WB, precipitating its participation in the R-PP process, though without WB funding. Following preparations made since 2008, Tanzania has also been a member of the UN Collaborative Programme on Reducing Emissions from Deforestation and Forest Degradation in Developing Countries [UNREDD] National Programme (2009-2012).

Both Tanzania's R-PP document and the first draft of the national REDD+ strategy appeared in late 2010 (United Republic of Tanzania [URT] 2010a; URT $2010 \mathrm{~b})$. As in the case of Mozambique, the documents differ radically. The R-PP is a highly technical report arguing the country's readiness for REDD+, whereas the first strategy draft analyzes both the technical preconditions of REDD+ and the possible social consequences of carbon sequestration and the commercialization of forest conservation, including benefit sharing with local and forestdependent people. It also takes a critical attitude toward Tanzania's administrative capacity to realize REDD+ (URT 2010b). Interestingly, the second strategy draft, which appeared in mid-2012, and the final version, from March 2013, follow the technical approach of the R-PP and emphasize the use of existing forest management structures and governance systems. The most important addition in the final version, relative to the second draft, is a closer examination of social and environmental safeguards, possibly added after IO consultations (URT 2012; URT 2013a).

In both the R-PP and strategy documents, the connection of REDD+ activities to global institutions is viewed primarily from a technical perspective. Due to carbon trading and its preconditions, the second drafted strategy emphasizes in particular the technical nature of some practices, such as MRV. In general, the practices are based on UNFCCC and Intergovernmental Panel on Climate Change good practice guidelines and form a national monitoring system involving data collection, modeling, and locating carbon emissions by geographic information systems. The draft further concludes that establishing a robust MRV system is a precondition for finalizing other system-based elements, including market- and regulation-enabling systems. The global governance structure of the Tanzanian REDD is obvious in the UN-REDD Programme Document, where the multilevel governance approach is clear and the global climate targets are monitored and managed through national and international bodies, including the Tanzanian Ministry of Natural Resources and Tourism (MNRT), the UN-REDD Policy Body, and the WB's FCPF participants' committee (UN-REDD 2009). 
In the final version of the strategy, the weight in strategic implementation is placed on strengthening existing conservation and forest management structures. The most important measures would take place in the public sector, particularly with respect to MRV, yet would also regard financial mechanisms and incentive schemes for REDD, the most important of which would be a national REDD+ trust fund (URT 2013a). The importance that the strategy documents give to decentralization, privatization, and commercialization is surprisingly weak. In fact, only one area of the strategic results considers the participation of the private sector and civil society, which is slated to occur within the existing participatory forest management (PFM) program (see Blomley and Iddi 2009). The document also partly stresses commercialization, including the market pricing of wood products and market-based forest certification, though these incentives are proposed to take place in the context of public forest governance, which is the central objective (URT 2012; URT 2013a). In the R-PP, by contrast, the role of nonstate actors is stronger, partly due to WB practices. The FCPF follows the WB's general rules, which require the participation of civil society and the private sector in the planning and realization of WB-funded undertakings (URT 2010a).

All versions of the strategy are based on the fund model. This may reflect an attempt to regulate carbon price through a national fund to guarantee a stable income for conservation, but alternatively, it may simply reflect the creation of a market institution facilitated by the state. The government's role is highlighted in the coordination of REDD+ projects as the legislator and facilitator for REDD+, roles that are crucial for making changes in the land-tenure system to provide secure land ownership for REDD+ schemes. Many other REDD-related measures similarly strengthen the government's grip on forest management and conservation (URT 2010b; URT 2012; URT 2013a).

In Tanzania, the REDD+ process is led by the Vice President's Office, while the MNRT (in the mainland) and the Ministry of Agriculture and Natural Resources (MANR, in Zanzibar) are the principal institutions in the REDD Task Force. Compared with Mozambique, the main difference is civil society's weak participation; until 2012, only one national CSO representative was included in the task force as an observer (Nhantumbo 2012). According to the strategy documents, local participation is to be achieved by the application of the PFM approach on village and private lands and state forests. However, the greatest problems posed by deforestation and the best opportunities for carbon storage are in so-called "general land forests," which constitute nearly half of the total forest area in Tanzania and suffer from open access, yet lie beyond the domain of PFM (URT 2010b).

In the R-PP model, the rules concerning civil society are first procedural and only secondly substantial (see Robinson et al. 2013). The governance system according to R-PP is based on existing national and local bodies, although it requires that some institutions, such as the National Climate Change Steering Committee and the related technical committee, be broadened to include CSOs 
and the private sector, as well as local communities. However, the WB's procedural rules concerning the latter's participation have not been translated into anchoring practices in the R-PP. Though the REDD process recognizes the rights of indigenous and forest-dependent peoples, it makes no attempt to define said rights in concrete terms, thereby making the procedural approach dubious (URT 2010a).

In contrast to the R-PP approach, the national strategy process has sought to develop the Cancun Safeguards into a concrete policy as a means to alleviate the social problems that international conservation interests have created. At least the first draft of the Tanzanian social and environmental standards (SES) suggests this (URT 2013b). The Cancun Safeguards emphasize that national legal and policy frameworks provide important environmental and social safeguards that apply to REDD+. In applying these criteria, the strategy addresses the WB's safeguard criteria and indicators, though the draft anticipates the emergence of Tanzanian SES providing detailed criteria and indicators for how to fulfill the eight social and environmental principles based on the seven Cancun Safeguards topics (URT 2013a). The SES draft divides further preparation into ten steps, the submission of the draft after public consultations being the sixth (URT 2013b). Clearly, detailed indicators in the draft help identify the particular national anchoring practices concerning IO procedure. Together with the national REDD strategy, SES form a distinguishable national REDD practice; yet, as a draft the SES may change considerably, as happened with the first national strategy draft. Nonetheless, if the final version of the safeguards follows the outline of the first draft, then Tanzania will have built a separate national anchoring practice. In technical issues it follows the IOs' procedural practices, but in social issues it seeks to develop its own practices.

\section{Conclusion: Mozambican and Tanzanian REDD+ Governance Practices in Comparison}

The analysis of Mozambican and Tanzanian national strategies and R-PP documents shows no consistent governance practices, but rather a mixture of IO policies and national practices. Interestingly, Tanzania in particular provides surprisingly weak connections to neoliberal environmental governance. The Mozambican strategy document shows a similar de-emphasis; excluding the Mozambican R-PP, the only anchoring practice in the strategy reflecting neoliberal environmental governance is the emphasis on civil society and public-private connections, which appears as an established procedure promoted by the WB to be subsequently adapted to the existing governance structures. In both countries, despite different participatory approaches practiced in REDD-related activities, the governments' grip is strong, leaving civil society and the private sector only minor roles in national strategies. The Mozambican R-PP deviates from this general line by highlighting a market-driven approach in carbon sequestration.

Table 2 reflects the initial dilemma faced by the governments in relation to the IOs when developing national REDD anchoring practices. Overall, the way 
Table 2

Mozambican and Tanzanian REDD+ Anchoring Practices

\begin{tabular}{|c|c|c|c|}
\hline Anchoring Practice & Neoliberal & Postnational & Government-Led \\
\hline $\begin{array}{l}\text { Connection to } \\
\text { global institutions }\end{array}$ & & $\begin{array}{l}\text { Tanzania } \\
\text { (NS1,2,3, R-PP) }\end{array}$ & $\begin{array}{l}\text { Mozambique } \\
\text { (NS) }\end{array}$ \\
\hline $\begin{array}{l}\text { Principles of } \\
\text { carbon sequestration } \\
\text { and mitigation }\end{array}$ & $\begin{array}{l}\text { Mozambique } \\
\text { (R-PP) }\end{array}$ & $\begin{array}{l}\text { Tanzania } \\
\text { (R-PP) }\end{array}$ & $\begin{array}{l}\text { Mozambique } \\
\text { (NS) } \\
\text { Tanzania } \\
(\mathrm{NS} 1,2,3)\end{array}$ \\
\hline $\begin{array}{l}\text { Principles of } \\
\text { funding }\end{array}$ & $\begin{array}{l}\text { Mozambique } \\
\text { (R-PP) }\end{array}$ & $\begin{array}{l}\text { Mozambique } \\
\text { (NS) } \\
\text { Tanzania } \\
\text { (R-PP) }\end{array}$ & $\begin{array}{l}\text { Tanzania } \\
(\mathrm{NS} 1,2,3)\end{array}$ \\
\hline $\begin{array}{l}\text { Principles of } \\
\text { governance }\end{array}$ & $\begin{array}{l}\text { Mozambique } \\
\text { (R-PP) }\end{array}$ & $\begin{array}{l}\text { Tanzania } \\
\text { (NS3) }\end{array}$ & $\begin{array}{l}\text { Mozambique } \\
\text { (NS) } \\
\text { Tanzania } \\
\text { (NS1) }\end{array}$ \\
\hline $\begin{array}{l}\text { Principles of } \\
\text { development }\end{array}$ & $\begin{array}{l}\text { Mozambique } \\
\text { (R-PP) }\end{array}$ & & \\
\hline
\end{tabular}

NS (1,2,3): National REDD+ Strategy (Drafts 1, 2, and 3)

the strategy is addressed in the Mozambican R-PP reflects the contradiction between their own national-level anchoring practices and practices from dominant IOs, such as the WB. While the strategy provides clear policy alignments on various momentous issues, including benefit-sharing mechanisms, institutional arrangements, and resource-tenure reforms, the R-PP treats these governmentled approaches as potential, albeit poorly developed, alternatives that stand on equal footing with neoliberal options (RM 2013b, 44-48, 83, 96-102). The strategy is unmistakably inadequate in terms of its detailed plans for REDD+ implementation. It does, however, provide a policy statement even though the WB did not endorse it. The subsequent injection of external funding from the WB and Japan, which resulted in the development of technical procedures (MRV, SES) compatible with UNFCCC guidelines, as well as specific REDD+ legislation, may reflect an emerging compromise in the form of postnational practices. In this context, practices reflect the opportunities available in a given situation of governments' versus IOs' and donors' interests.

The Tanzanian REDD+ documents are more successful in reconciling national strategy and the R-PP without compromising the government's role in the REDD+ process. The practices adopted to implement REDD+ essentially follow the same practices observed in Tanzania's environmental governance elsewhere, 
such as in the PFM program. Doubtlessly, REDD has pressured the government to commercialize and privatize the forest sector for carbon markets, though the establishment of institutions of carbon trade, including the national fund and the MRV system, as well as environmental and social safeguards, tend to strengthen the government's grip on environmental governance and forest management (cf. Robinson et al. 2013).

As such, we are inclined to suggest, with certain reservations, that the emphasis in our case studies falls more on government-led practices and, to a certain extent, postnational practices. In the Mozambican strategy, the connection to global institutions occurs through national institutions, and carbon sequestration is merely a side project of the overall development effort, not a goal. This situation is, however, difficult to reconcile with the market-driven approach of the R-PP, although the recent development of standardized technical practices and a new legal framework, achieved with external funding, appears to represent a compromise. In the Tanzanian case, though the government's role is dominant, the connection to global institutions and the role of mitigation represent mixed practices. Both the national strategy and the R-PP reveal an apparent goal of, and procedures for, mitigation, which are proposed to occur due to public and private measures by combining development and conservation policies and mechanisms. In the case of funding, both countries base their REDD strategy on national funding, which can be financed by any combination of global climate funds, private carbon trade schemes, and development assistance. However, at the same time pilot projects drawing on voluntary carbon markets continue on the side. To the extent that the REDD+ projects are funded, Tanzanian documents suggest that the country's development goals are secured by way of the safeguards, despite large-scale conservation projects. In Mozambique, where the objectives concerning mitigation are not as apparent as in Tanzania, the development of safeguards with external funding is more recent, and conventional development assistance is emphasized.

In light of the Mozambican and Tanzanian REDD documents, postnational practices can be considered an outcome of global climate governance practices, which include global standards, covering marketization, democratization and civil society participation, and governments' attempts to keep their established practices. Postnational practices reflect the current state of affairs in global climate and development regimes. Clearly IOs, and the WB in particular, put relatively strong pressure on REDD target countries via R-PPs to adapt market practices in REDD+, as the Mozambican case indicates; their overall role in the realization of REDD+ governance as an emerging practice is obscure. Therefore, although our major interest has been in how a global initiative becomes transformed into national practices, the process is actually bidirectional; the discussion addressing the FVA in the UNFCCC is a clear example of interaction in the adaptation of different domestic mitigation approaches within global climate governance. The compromise reached in Bonn in June 2015 seems to suggest a flexible approach that gives relatively large latitude for instituting national practices. 


\section{References}

Adler, Emanuel, and Vincent Pouliot. 2011. International Practices: Introduction and Framework. In International Practices, edited by Emanuel Adler and Vincent Pouliot, 3-35. Cambridge: Cambridge University Press.

Arsel, Murat and Bram Büscher. 2012. Nature ${ }^{\mathrm{TM}}$ Inc.: Changes and Continuities in Neoliberal Conservation and Market-based Environmental Policy. Development and Change 43: 53-78.

Arts, Bas, Jelle Behagel, Esther Turnhout, Jessica de Koning, and Severine van Bommel. 2014. "A Practice Based Approach to Forest Governance." Forest Policy and Economics 49: 4-11.

Beymer-Farris, Betsy, and Thomas Bassett. 2012. The REDD Menace: Resurgent Protectionism in Tanzania's Mangrove Forests. Global Environmental Change 22: 332-341.

Blomley, Tom, and Said Iddi. 2009. Participatory Forest Management in Tanzania: 19932009. Lessons Learned and Experiences to Date. Dar es Salaam: Ministry of Natural Resources and Tourism.

Brockington, Daniel, and Rosaleen Duffy. 2010. Capitalism and Conservation: The Production and Reproduction of Biodiversity Conservation. Antipode 42: 469-484.

Castree, Noel. 2008a. Neoliberalising Nature: The Logics of Deregulation and Reregulation. Environment and Planning 40: 131-152.

Castree, Noel. 2008b. Neoliberalising Nature: Processes Effects, and Evaluations. Environment and Planning 40: 153-173.

CDM Rulebook. 2012. Available at http://cdmrulebook.org, accessed August 3, 2012.

CIP and AWEPA. 2012. Carbon Traders Want Access to 1/3 of Mozambique Under REDD+, but MICOA Says No. Mozambique Political Process Bulletin 50, July 9, 2012. Available at www.cip.org.mz/bulletin/en/index.asp, accessed August 20, 2013.

Corbera, Esteve. 2012. Problematizing REDD+ as an Experiment in Payments for Ecosystem Services. Current Opinion in Environmental Sustainability 4: 612-619.

Daviet, Florence, and Gaia Larsen. 2012. Safeguarding Forests and People: A Framework for Designing a National System to Implement REDD+ Safeguards. Washington, DC: World Resources Institute.

den Besten, Jan Willem, Bas Arts, and Patrik Verkooijen. 2014. The Evolution of REDD+: An Analysis of Discursive-Institutional Dynamics. Environmental Science \& Policy 35: 40-48.

Doherty, Emma and Heike Schroeder. 2011. "Forest Tenure and Multi-level Governance in Avoiding Deforestation under REDD+." Global Environmental Politics 11 (4): 66-88.

Dooley, Kate, Tom Griffiths, Francesco Martone, and Saskia Ozinga. 2011. Smoke and Mirrors: A Critical Assessment of the Forest Carbon Partnership Facility. Moreton-inMarsh, UK: FERN and Forest Peoples Programme.

ENB. 2015. Summary of the Bonn Climate Change Conference. Earth Negotiations Bulletin 12 (638), 14 June, 2015. Available at www.iisd.ca/vol12/enb12638e.html, accessed July 4, 2015.

Fletcher, Robert. 2012. Using the Master's Tools? Neoliberal Conservation and the Evasion of Inequality. Development and Change 43: 295-17.

Forest Carbon Partnership Facility [FCPF]. 2014. REDD+ Readiness Progress Fact Sheet: Mozambique, May 2014. Available at www.forestcarbonpartnership.org/sites/fcp/ files/2014/June/FCPF, accessed August 17, 2014. 
Gupta, Joyeeta. 2012. Glocal Forest and REDD+ Governance: Win-Win or Lose-Lose? Current Opinion in Environmental Sustainability 4: 620-627.

Gupta, Joyeeta, Nicolien van der Grijp, and Onno Kuik, eds. 2013a. Climate Change, Forests and REDD: Lessons for Institutional Design. London: Routledge.

Gupta, Joyeeta, Robin Mathews, Patrick Meyfroidt, Constance Haug, Onno Kuik, and Nicolien van der Grijp. 2013b. Future of the Forest. In Climate Change, Forests and REDD: Lessons for Institutional Design, edited by Joyeeta Gupta, Nicolien van der Grijp, and Onno Kuik, 229-258. London: Routledge.

Habermas, Jürgen. 2001. The Postnational Constellation: Political Essays. Edited and translated by Max Pensky. Cambridge, MA: MIT Press.

Haug, Constanze, and Joyeeta Gupta. 2013. The Emergence of REDD on the Global Policy Agenda. In Climate Change, Forests and REDD: Lessons for Institutional Design, edited by Joyeeta Gupta, Nicolien van der Grijp, and Onno Kuik, 77-98. London: Routledge.

Hayes, Tanya, and Lauren Persha. 2010. Nesting Local Forestry Initiatives: Revisiting Community Forest Management in a REDD+ World. Forest Policy and Economics 12: 545-553.

Hedrick, Todd. 2007. Constitutionalization and Democratization: Habermas on Postnational Condition. Social Theory and Practice 33: 387-410.

Herbertson, Kirk. 2012. Will Safeguards Survive the Next Generation of Development Finance? Berkeley, CA: International Rivers.

Holmes, George. 2011. "Conservation's Friends in High Places: Neoliberalism, Networks, and the Transnational Conservation Elite." Global Environmental Politics 11 (4): 1-21.

Humphreys, David. 2003. "Life Protective or Carcinogenic Challenge? Global Forest Governance under Advanced Capitalism." Global Environmental Politics 3 (2): 40-55.

Humphreys, David. 2009. Discourse as Ideology: Neoliberalism and the Limits of International Forest Policy. Forest Policy and Economics 11: 319-325.

Igoe, Jim, and Dan Brockington. 2007. Neoliberal Conservation: A Brief Introduction. Conservation and Society 5: 432-449.

Jessop, Bob. 2004. Hollowing Out the "Nation-State" and Multi-Level Governance. In A Handbook of Comparative Social Policy, edited by Patricia Kennett, 11-25. Cheltenham, UK: Edward Elgar.

Kashwan, Prakash. 2015. "Forest Policy, Institutions, and REDD+ in India, Tanzania, and Mexico." Global Environmental Politics 15 (3): 95-117.

Lansing, David. 2011. Realizing Carbon's Value: Discourse and Calculation in the Production of Carbon Forestry Offsets in Costa Rica. Antipode 43: 731-753.

Makundi, Willy. 2011. African Forests and Trees in the Global Carbon Market. In Climate Change and African Forest and Wildlife Resources, edited by Emmanuel Chidumayo, David Okali, Godwin Kowero, and Muhamane Larwanou, 192-213. Nairobi: African Forest Forum.

McAffee, Katheleen. 2012. The Contradictory Logic of Global Ecosystem Services Markets. Development and Change 43: 105-131.

McCarthy, James. 2005. Devolution in the Woods: Community Forestry as Hybrid Neoliberalism. Environment and Planning 37: 995-1014.

McDermott, Constance, Kelly Levin, and Benjamin Cashore. 2011. "Building the Forest Climate Bandwagon: REDD+ and the Logic of Problem Amelioration." Global Environmental Politics 11 (3): 85-103. 
Milne, Sarah, and Bill Adams. 2012. Market Masquerades: Uncovering the Politics of Community-Level Payments for Environmental Services in Cambodia. Development and Change 43: 133-158.

Ministry of Coordination of Environmental Affairs [MICOA]. 2011. Proposta de Estratégia de Redução de Emissões por Desmatamento e Degradação Florestal. Mimeographed document. Maputo, Mozambique: MICOA.

Murdiyarso, Daniel, Maria Brockhaus, William D. Sunderlin, and Lou Verchot. 2012. Some Lessons Learned from the First Generation of REDD+ Activities. Current Opinion in Environmental Sustainability 4: 678-685.

Mustalahti, Irmeli, Anna Bolin, Emily Boyd, and Jouni Paavola. 2012. Can REDD+ Reconcile Local Priorities and Needs with Global Mitigation Benefits? Lessons from Angai Forest, Tanzania. Ecology and Society 17 (1): 16. doi:10.5751/ES-04498-170116 Mwakalobo, Adam, George Kajembe, Dos Santos Silayo, Emmanuel Nzunda, Eliakimu Zahabu, Salim Maliondo, and D. N. Kimaro. 2011. REDD and Sustainable Development: Perspective from Tanzania. London: International Institute for Environment and Development.

Nhamo, Godwell, and Alfred Bimha. 2011. Carbon Pricing in Cap-and-Trade Systems: International Perspectives and Lessons for Africa. In Green Economy and Climate Mitigation: Topics of Relevance to Africa, edited by Godwell Nhamo, 103-129. Pretoria: Africa Institute of South Africa.

Nhantumbo, Isilda. 2011. REDD+ in Mozambique: New Opportunity for Land Grabbers? Available at www.iied.org/blogs/redd-mozambique-new-opportunity-for-landgrabbers, accessed June 10, 2012.

Nhantumbo, Isilda. 2012. Getting REDD-Ready: Two Models of Coordination and Engagement from Africa. International Institute for Environment and Development Briefing. Available at http://pubs.iied.org/17139IIED.html, accessed December 12, 2014.

Odgaard, Rie, and Faustin Maganga. 2009. Indigenous Peoples and Forest ManagementBefore and After REDD: The Case of Tanzania. Indigenous Affairs 1-2/09: 21-27.

Okereke, Chukwumerije, and Kate Dooley. 2010. Principles of Justice in Proposals and Policy Approaches to Avoided Deforestation: Towards a Post-Kyoto Climate Agreement. Global Climate Change 20: 82-95.

Olander, Lydia, Christopher Galik, and Gabrielle Kissinger. 2012. Operationalizing REDD+: Scope of Reduced Emissions from Deforestation and Forest Degradation. Current Opinion in Environmental Sustainability 4: 661-669.

Peck, Jamie, and Adam Tickell. 2002. Neoliberalizing Space. Antipode 34: 380-404.

Phelps, Jacob, Edward Webb, and Arun Agrawal. 2010. Does REDD+ Threaten to Recentralize Forest Governance? Science 328 (5976): 312-313.

Pistorius, Till. 2012. From RED to REDD+: The Evolution of a Forest-Based Mitigation Approach for Developing Countries. Current Opinion in Environmental Sustainability 4: 638-645.

Pülzl, Helga, Daniela Kleinschmit, and Bas Arts. 2014. Bioeconomy-An Emerging MetaDiscourse Affecting Forest Discourses? Scandinavian Journal of Forest Research 29: 386-393.

Quan, Julian, Lars Naess, Andrew Newsham, Almeida Sitoe, and Maria Fernandez. 2014. Carbon Forestry and Climate Compatible Development in Mozambique: A Political Economy Analysis. IDS Working Paper 448, Institute of Development Studies, Brighton, UK. 
Republic of Mozambique [RM]. 2013a. Decree 70/2013 (Decreto no. 70/2013 de 20 de Dezembro). Boletim da República, I Série (no. 102): 1066-1074.

Republic of Mozambique [RM]. 2013b. Forest Carbon Partnership Facility Mozambique Readiness Preparation Proposal. January 2013.

Rhodes, Rod. 1994. The Hollowing Out of the State: The Changing Nature of the Public Services in Britain. Political Quarterly 65: 138-151.

Robinson, Elizabeth, Heidi Albers, Charles Meshack, and Razack Lokina. 2013. Implementing REDD Through Community-Based Forest Management: Lessons from Tanzania. Natural Resources Forum 37: 141-152.

Ruckert, Arne. 2006. Towards an Inclusive Neoliberal Regime of Development: From the Washington to the Post-Washington Consensus. Labour, Capital and Society 39: 35-67.

Sangmpam, S. N. 2007. Politics Rules: The False Primacy of Institutions in Developing Countries. Political Studies 55: 201-224.

Scheuerman, William. 2008. Global Governance Without Global Government? Habermas on Postnational Democracy. Political Theory 36: 133-149.

Sending, Ole and Iver Neumann. 2011. Banking on Power: How Some Practices in an International Organization Anchor Others. In International Practices, edited by Emanuel Adler and Vincent Pouliot, 231-254. Cambridge: Cambridge University Press.

Sitoe, Almeida, Alda Salomão, and Sheila Wertz-Kanounikoff. 2012. O Contexto de REDD+ em Moçambique: Causas, Actors e Instituições. Bogor, Indonesia: Center for International Forestry Research.

Somorin, Olufunso, Carolyn Peach Brown, Ingrid Visseren-Hamakers, Denis Sonwa, Bas Arts, Johnson Nkem. 2012. The Congo Basin Forests in a Changing Climate: Policy Discourses on Adaptation and Mitigation (REDD+). Global Environmental Change 22: $288-298$.

Streck, Charlotte. 2012. Financing REDD+: Matching Needs and Ends. Current Opinion in Environmental Sustainability 4: 628-637.

Stephan, Benjamin. 2012. Bringing Discourse to the Market: The Commodification of Avoided Deforestation. Environmental Politics 21: 621-639.

Swidler, Ann. 2001. What Anchors Cultural Practices? In Practice Turn in Contemporary Theory, edited by Theodore R. Schatzki, 84-102. New York: Routledge.

UN Collaborative Programme on Reducing Emission from Deforestation and Forest Degradation in Developing Countries [UN-REDD]. 2009. National Programme Document, Tanzania, December 9, 2009.

United Nations Framework Convention on Climate Change [UNFCCC]. 2012. Glossary of CDM Terms, Version 7.0. Clean Development Mechanism Executive Board. Available at http://cdm.unfccc.int/Reference/Guidclarif/glos_CDM.pdf, accessed December 12, 2014.

United Republic of Tanzania [URT]. 2010a. Forest Carbon Partnership Facility Tanzania Readiness Preparation Proposal (FCPFR-PP), October 12, 2010.

United Republic of Tanzania [URT]. 2010b. National Strategy for Reduced Emissions from Deforestation and Forest Degradation (REDD+), Draft. December 2010. Available at www.unredd.net, accessed August 21, 2012.

United Republic of Tanzania [URT]. 2012. National Strategy for Reduced Emissions from Deforestation and Forest Degradation (REDD+), 2nd draft. June 2012. Available at www.unredd.net, accessed September 24, 2013. 
United Republic of Tanzania [URT]. 2013a. National Strategy for Reduced Emissions from Deforestation and Forest Degradation (REDD+). March 2013. Available at www.redtz.org, accessed October 19, 2014.

United Republic of Tanzania [URT]. 2013b. Tanzania REDD+ Social and Environmental Standards. June 2013. Available at www.unredd.net, accessed October 16, 2014.

West, Simon. 2010. "Command Without Control": Are Market Mechanisms Capable of Delivering Ecological Integrity to REDD? Law, Environment and Development Journal 6: 299-319.

World Bank. 2013. Second Grant Agreement for Mozambique Readiness Preparation Proposal: Readiness Fund for the FCPF. Grant No. TF011206. 